\title{
Lungworm infection with Otostrongylus circumlitus in a free-ranging harbor seal (Phoca vitulina)
}

\author{
Longworm infectie met Otostrongylus circumlitus \\ bij een wilde gewone zeehond (Phoca vitulina)
}

${ }^{1}$ L. Geerinckx, ${ }^{1}$ A. Jonker, ${ }^{1}$ L. Van Brantegem, ${ }^{2}$ P. De Laender, ${ }^{3}$ N. De Wilde, ${ }^{3}$ E. Claerebout, ${ }^{1}$ K. Chiers

\begin{abstract}
${ }^{1}$ Department of Pathology, Bacteriology and Avian Diseases, Faculty of Veterinary Medicine, Ghent University, Salisburylaan 133, B-9820 Merelbeke, Belgium

${ }^{2}$ Sea Life Blankenberge, Prins Karellaan 39, B-8310 Blankenberge, Belgium

${ }^{3}$ Department of Virology, Parasitology and Immunology, Faculty of Veterinary Medicine,

Ghent University, Salisburylaan 133, B-9820 Merelbeke, Belgium
\end{abstract}

lise.geerinckx@UGent.be

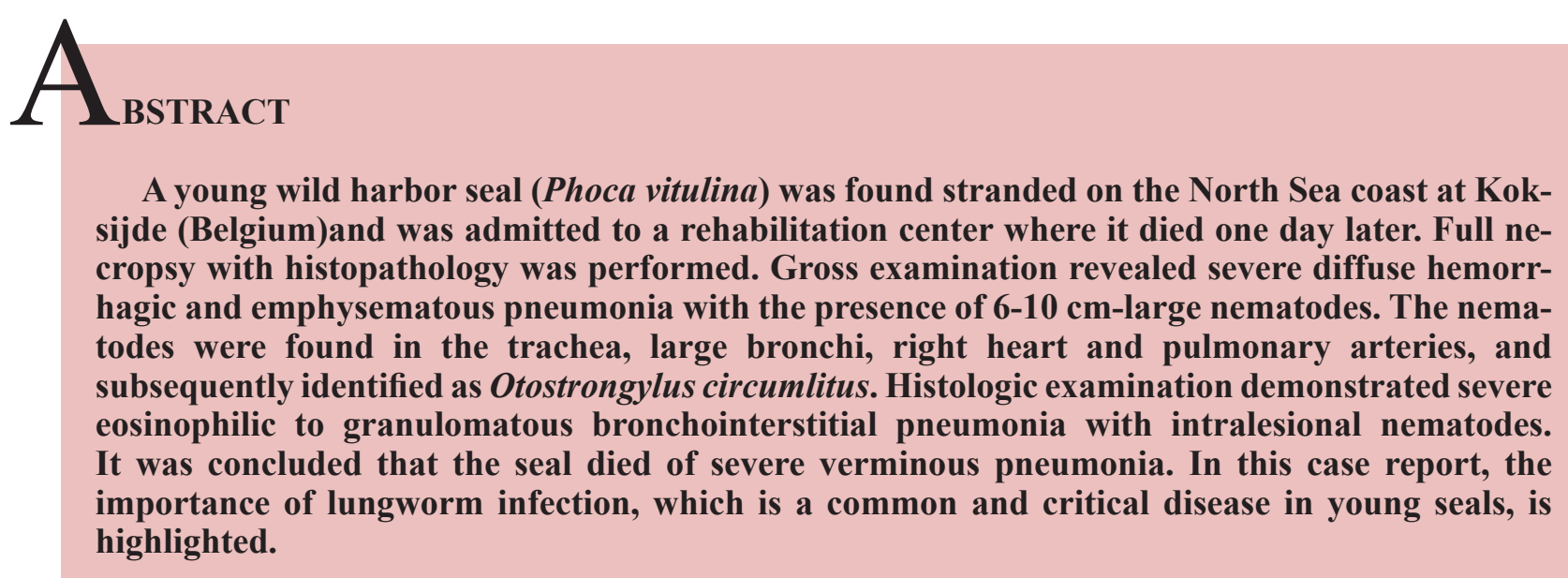

\section{SAMENVATTING}

Een jonge wilde gewone zeehond (Phoca vitulina) spoelde aan op het strand ter hoogte van Koksijde en werd opgenomen in een rehabilitatiecentrum waar hij na één dag stierf. Een volledige autopsie met histopathologisch onderzoek werd uitgevoerd. Macroscopische evaluatie toonde ernstige diffuse hemorragische en emfysemateuze pneumonie met aanwezigheid van 6-10 cm-grote nematoden aan. De nema-toden werden gevonden in de trachea, grote bronchen, pulmonaire arteriën en in het rechterhart. Ze werden geïdentificeerd als Otostrongylus circumlitus. Tijdens het histologisch onderzoek werd ernstige eosinofiele tot granulomateuze broncho-interstitiële pneumonie met intralesionale nematoden vastgesteld. Er werd geconcludeerd dat de zeehond stierf ten gevolge van uitgebreide vermineuze pneumonie. In deze casus-beschrijving wordt het belang van longworminfectie, een vaak voorkomende en ernstige aandoening bij jonge zeehonden, benadrukt.

\section{INTRODUCTION}

Otostrongylus circumlitus is a large parasitic metastrongyloid nematode of the Crenosomatidae family. It is only one of several species of respiratory and cardiovascular nematodes commonly observed in pinnipeds, such as small lungworms from the family Filaroididae and heartworms belonging to the fam- ily Filariidae. Free-ranging pinnipeds frequently suffer from mixed infections of these parasites, which is often complicated by secondary bacterial infection (Measures, 2001). In a study by Ulrich et al. (2016), the lungworm seroprevalence in weaned North Sea harbor seals was found to be up to $88.9 \%$.

The distribution of $O$. circumlitus is holartic and circumpolar, mainly restricted to the Northern hemi- 
sphere. It can infect a variety of pinnipeds, with harbor seals (Phoca vitulina) and ringed seals (Phoca hispida) functioning as main primary hosts (Bergeron et al., 1997; Gulland et al., 1997; Elson-Riggins et al., 2001; Measures, 2001; Leidenberger and Boström, 2009; Colegrove et al., 2018). The course of the disease seems to be highly dependent on several host factors, including species and age. For example, the localization of the adult nematodes in the host body is correlated with the affected species of pinniped (Gulland et al., 1997; Elson-Riggins et al., 2001; Measures, 2001; Leidenberger and Boström, 2009), and Lehnert et al. (2007) found the adult nematode respiratory burden to be highly age-related.

Knowledge about the complete life cycle of $O$. circumlitus is limited, but it is known that the larvae produced by adult females are released into the airways, where they are swallowed and passed with the feces (Lehnert et al., 2010). Fish, such as benthic fish species, then perform the role of intermediate hosts, harboring encapsulated larvae in their intestinal serosa and/or in the body cavity (Bergeron et al., 1997). Crustaceans and mollusks seem to serve as paratenic hosts. However, the exact transmission of the marine lungworm larvae is not yet fully understood (Ulrich et al., 2016). In harbor seals, the adult nematodes mainly reside in the trachea, bronchi and bronchioles, and are only occasionally observed in the right heart and pulmonary arteries (Gulland et al., 1997; ElsonRiggins et al., 2001; Measures, 2001; Leidenberger and Boström, 2009). They are typically reversely oriented relative to their host, with their anterior ends embedded into lung parenchyma and their posterior ends extending towards the upper airways (Gosselin et al., 1998).

As concurrent infections by multiple parasites are commonplace, linking clinical symptoms to specific parasites can be challenging (Onderka, 1989; Munro et al., 1992; Measures, 2001). Nonetheless, a tentative diagnosis of lungworm infection can be based on respiratory clinical signs, such as dyspnea, bronchospasms, expectoration of blood and/or mucus and variably blood-tinged nasal discharge (Measures, 2001). Clinical confirmation of Otostrongylus infections is difficult due to the low sensitivity of assays for detection of larvae in feces or respiratory mucus (Ulrich et al., 2016) and a lack of available assays demonstrating infection during the prepatent period (Dailey, 2001). In 2015, an ELISA developed for the bovine lungworm Dictyocaulus viviparus was adapted for detection of antibodies against $O$. circumlitus in harbor and grey seals, demonstrating a high sensitivity and specificity (Ulrich et al., 2016). Medical imaging techniques such as radiology (RX), magnetic resonance imaging (MRI), computed tomography (CT) and echocardiography can be used to assess anomalies at the level of heart and lungs, but this can be costly and requires adequate equipment and experience (Dennison and Saviano, 2001).
Gross lesions related to lungworm infection in seals are variable and include a range of lung lesions, such as congestion, bronchitis and bronchopneumonia, ranging from severe obstructive suppurative to necrotizing (Gulland et al., 1997; Measures, 2001; Siebert et al., 2007; Leidenberger and Boström, 2009). If a secondary bacterial infection is present, it can result in diffuse suppurative pneumonia and abscess formation (Gulland et al., 1997; Measures, 2001; Siebert et al., 2007). Granuloma formation in lung tissue has been seen accompanying degeneration of the nematodes (Onderka, 1989). Chronic infections can cause interlobular fibrosis. Mild arteritis is sometimes present, likely due to migration of larvae (Gulland et al., 1997). Histologically, alveoli are consistently filled with an exudate containing foamy macrophages, eosinophils and neutrophils. Even in subclinically affected animals, a moderate lymphoplasmacytic and eosinophilic peribronchitis with goblet cell hyperplasia as well as a mild chronic arteritis with intima hyperplasia has been observed (Munro et al., 1992; Colegrove et al., 2018).

Lungworm infections in seals can be treated with broad-spectrum anthelmintics, such as benzimidazoles or macrocyclic lactones, e.g. $0.2 \mathrm{mg} / \mathrm{kg}$ ivermectin p.o. or $0.2 \mathrm{mg} / \mathrm{kg}$ moxidectin SC (Vercruysse et al., 2003) or a combined therapy of ivermectin and fenbendazole (Stoskopf, 2015). Therapy of captive and rehabilitated pinnipeds has to be undertaken with a certain degree of caution (Munro et al., 1992; Measures, 2001), as the resulting die-off of parasites can trigger secondary allergic reactions and/or thrombosis of pulmonary vessels (Munro et al., 1992). Low initial dosage and a combination strategy using antihistamines and adrenocorticotropic agents can lower the chances of these complications (Measures, 2001). Per individual case, additional treatment options for excessive mucus, secondary bacterial infection, shock and/or dehydration should be considered (Moesker, 1987, Vercruysse et al., 2003).

\section{CASE REPORT}

A free-ranging male harbor seal (Phoca vitulina), found stranded on the North Sea coast at Koksijde, was admitted to a rehabilitation center in Blankenberge (SeaLife) in October, 2019. His age was estimated to be around six to seven months at the facility. The body weight was $18,8 \mathrm{~kg}$. The animal was lightly aggressive and showed a normal activity and appetite. Lungworm infection was suspected based on the presence of nasal sputum and indications of pneumonia during auscultation. Hence, fenbendazole (Panacur, MSD Animal Health, USA, $1 \mathrm{mg} / \mathrm{kg}$ ) was given orally on the day of referral to the rehabilitation center. The animal unexpectedly died less than 24 hours after this administration and was necropsied the day after.

On external evaluation of the carcass, multifocal 
discrete old skin lesions were found at the level of the trunk (scars), as well as three more recent superficial skin lesions on the right hind limb. The body condition was judged to be within normal limits, with the presence of a decent blubber thickness, fat reserves in peritoneal cavity and a normal level of musculature. Internally, severe diffuse hemorrhagic pneumonia was observed (Figure 1A). The lungs showed severe interstitial emphysema and multifocal superficial and parenchymatous bleeding (Figure 1B). Multiple white nematodes of approximately $10 \mathrm{~cm}$ long and $2 \mathrm{~mm}$ thick were present in the lumen of the bronchi and lung arteries (Figure 1C). No macroscopic thrombi were present. The tracheal lumen was filled with twenty non-adhered white nematodes and a moderate amount of hemorrhagic mucus. The tracheal mucosa showed discrete small hemorrhages. Twenty white nematodes with a length of 6 to $7 \mathrm{~cm}$ were present in the right cardiac ventricle and atrium (Figure 1D). The liver had a small hematoma in the right medial lobe. The stomach contained a few smaller white nematodes (with a length of 2 to $3 \mathrm{~cm}$ ). The stomach mucosa was mildly congested. Three large (up to 50 $\mathrm{cm}$ ), non-adhered, white-to-light yellow tapeworms were present in the small intestine. The other organs showed no macroscopic abnormalities.

Histologically, severe multifocal chronic granulomatous and mild eosinophilic pneumonia with intralesional nematodes was observed (Figures 2A and 2B). Different life cycle stages of nematode species were present. Cross- and longitudinal sections of nematode larvae, recognizable by their lack of a genital tract, were found throughout the lung parenchyma (Figure 2C). A severe diffuse eosinophilic and moderate suppurative inflammation and goblet cell hyperplasia were present at the level of the large bronchi. Their lumen also contained several 500-800 $\mu \mathrm{m}$ cross-sections of adult nematodes (Figures 2D and 2E). These were composed of light eosinophilic cuticula, a coelomyarian musculature, an intestinal tract and a genital tract containing embryonated eggs and larvae. Bronchial epithelial cells were hyperplastic and showed loss of cilia. A severe peribronchial lymphoplasmacytic inflammation extended into the peribronchial glands (Figure 2D, asterisk). Some arteries demonstrated mild endothelial hyperplasia or were moder-


Figure 1. A. Severe diffuse bilateral hemorrhagic pneumonia and emphysema. B. Cross section of right lung demonstrating the extent of parenchymal involvement. C. Bronchial bifurcation with Otostrongylus circumlitus in the right bronchus. D. Lumen of right cardiac ventricle contains several nematodes. 
ately to severely dilated. One artery contained multiple sections of analogous nematodes (Figure 2F). It was concluded that the seal died of diffuse severe eosinophilic-granulomatous hemorrhagic bronchointerstitial pneumonia and diffuse severe lymphoplasmacytic bronchitis, caused by a lungworm infection.
Based on the morphologic examination, the adult nematodes found in the heart, lungs and trachea were identified as Otostrongylus circumlitus by the Department of Parasitology, Faculty of Veterinary Medicine, Ghent University (Figure 3A). They had a transparent cuticle, which was moderately swollen at the anterior


Figure 2. A and B. Diffuse severe eosinophilic-purulent-granulomatous bronchointerstitial pneumonia. C. Larvae of Otostrongylus circumlitus in interstitium. D. Adult nematodes in the bronchial lumen. Lymphoplasmacytic peribronchitis (asterisk). E. Close-up of a cross section of an adult Otostrongylus circumlitus. F. Multiple sections of $O$. circumlitus in a large vessel. All histologic slides are HE-stained. A. Magnifications are 100x, B. 400x, C. 100x, D. 50x, E. 100x and F. 50x. Scalebar represents $100 \mu \mathrm{m}$. 

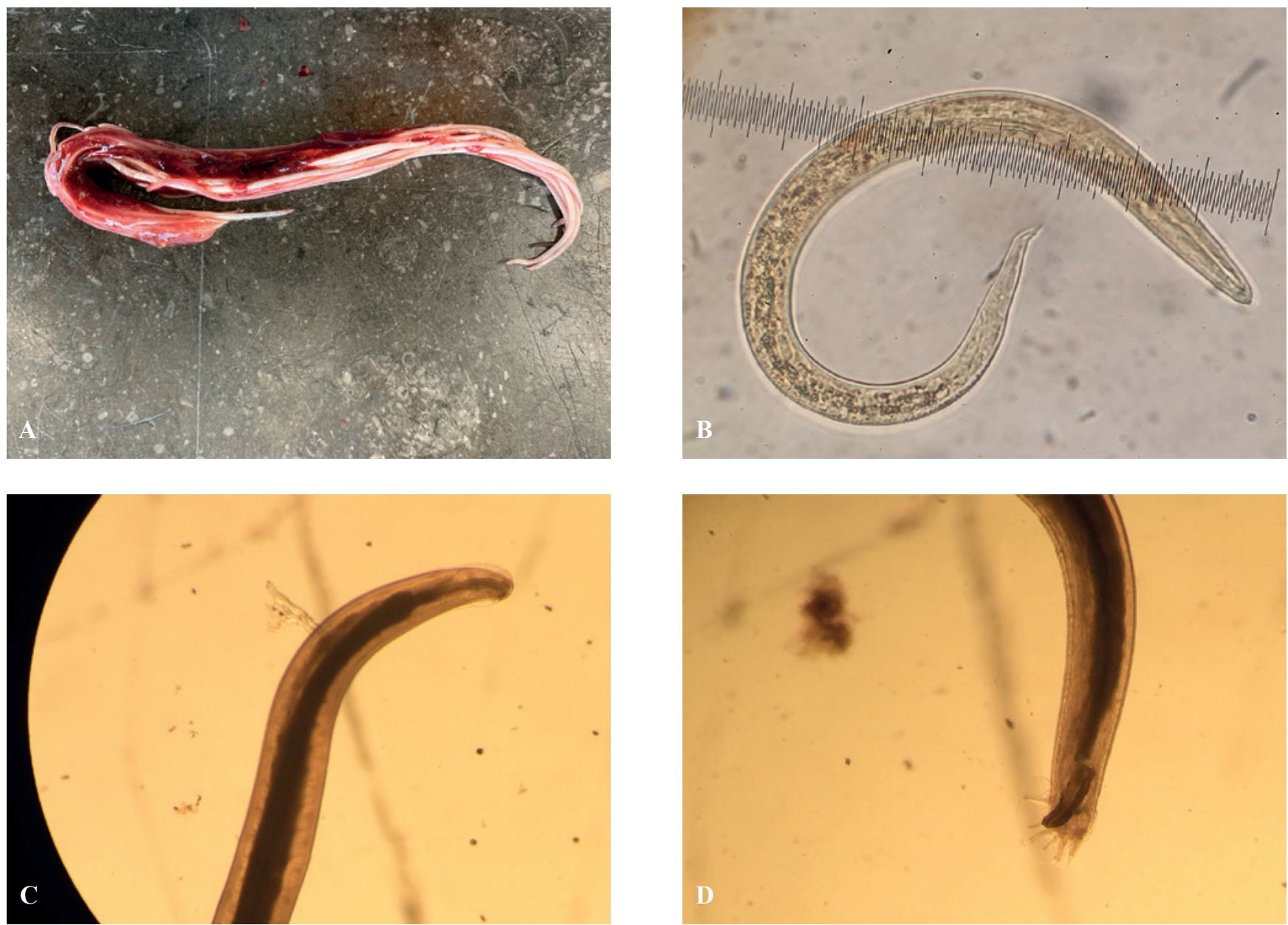

Figure 3. Otostrongulus circumlitus. A. Gross appearance of adults. B. L1-stage. C. Anterior end of adult male and female worms. D. Posterior end of adult male worm.

end (i.e. esophageal bulb) (Figure 3C). Male adults possess paired short, stout spicules and a bursa copulatrix supported by short rays (Figure 3D). Gravid female adults contain intrauterine eggs and L1 larvae (Figure 3B). The intestinal tapeworms were identified as Diphyllobothrium spp..

\section{DISCUSSION}

In this juvenile harbor seal, a classic case of a severe lungworm infection with Otostrongylus circumlitus is represented. The estimated age of six to seven months fits into the most susceptible age groups, as reported in free-ranging harbor seals in Germany and stranded seals in the Netherlands (Claussen et al., 1991; Siebert et al., 2007; Ulrich et al., 2016). The animal stranded and died in October 2019, which slightly contrasts to the findings in a study by Van Wijngaarden et al. (2021). In that study, a significantly decreased mortality was observed of juvenile seals infected with lungworm stranded between August and December compared to strandings between January and May. Although mixed parasitic infections are common in free-ranging pinnipeds, all nematodes found in the trachea and lungs that were examined, were identified as $O$. circumlitus and no small lungworms nor heart worms were found. It warrants mentioning that these other nematodes, such as the frequently concurrent Parafilaroides gymnurus, may have been overlooked macroscopically due to their generally smaller size and delicate appearance (Elson-riggins et al., 2020).

The gross findings at necropsy were consistent with the described macroscopic lesions mentioned in the literature (Gulland et al., 1997; Measures, 2001; Leidenberger and Boström, 2009), although no evidence of secondary bacterial lung infection was seen. The histopathologic results of this case report also reflect the lesions described in severe infections (Onderka, 1989; Munro et al., 1992; Gulland et al., 1997; Leidenberger and Boström, 2009; Colegrove et al., 2018).

In the present case, monotherapy with fenbendazole was initiated, which is commonly used by the treating practitioner and which results in a high survival rate in seals. The veterinarian who treated the seal in this case usually reserves combination treatment strategies with antibiotic compounds (predominantly 
amoxicillin-clavulanate) for seals with more severe clinical signs, mindful of antibiotic resistance development. If signs of dyspnea and/or suffocation should arise, they would be treated with supplementary antihistamines and corticosteroids. Dailey (2001) suggests starting therapy with dexamethasone and antibiotics, at least three days before administrating any anthelmintic. Complications from anthelmintic treatment are mostly seen when there are large numbers of lungworms present in the right ventricle and pulmonary artery (Munro et al., 1992).

This particular incident of sudden death without observed preliminary symptoms of shock and/or severe coughing, was considered rather unusual in the experience of the veterinary practitioner. It could be argued that the high parasite burden of over forty adult worms could have proven fatal (Clausen and Bjarne, 1978). Presumably, a die-off of parasites as a result of anthelmintic treatment contributed to mortality in this case, possibly due to obstruction of the major airways or vessels, or hypersensitivity reactions inducing anaphylactic shock (Vercruysse et al., 2003). It can be concluded that the high prevalence of lungworms in young-of-the-year seals in the North Sea area warrants a cautionary therapeutic approach to these stranded animals.

\section{ACKNOWLEDGEMENTS}

The authors would like to thank the Blankenberge SeaLife team for their submission of the carcass for necropsy and for sharing their experience and knowledge with the authors, as well as the technicians of the laboratories of Veterinary Pathology and Parasitology (Faculty of Veterinary Medicine, Ghent University) for their assistance, effectively making this case report possible.

\section{LITERATURE}

Bergeron E., Measures L.N., Pettorelli J.H. (1997). Experimental transmission of Otostrongylus circumlitus (Railliet, 1899) (Metastrongyloidae: Crenosomatidae), a lungworm of seals in eastern arctic Canada. Canadian Journal of Zoology 75, 1364-1371.

Clausen B., Bjarne (1978). Diseases and toxochemicals in the common seal in Denmark. Riistatieteellisia Julkaisuja 37, 38-39.

Colegrove K.M., Burek-Huntington K.A., Roe W., Siebert U. (2018). Pinnipediae. In: Terio K.A., McAloose D., St. Leger J. (editors). Pathology of Wildlife and Zoo Animals. First edition, Elsevier, London, 583-585.

Claussen D., Strauss V., Ising S., Jäger M., Schnieder T., Stoye M. (1991). The helminth fauna of the common seal (Phoca vitulina vitulina, Linne, 1758) of the Wadden Sea in lower Saxony. Journal of Veterinary Medicine 38, 649-656.

Dailey M.D. (2001). Parasitic diseases. In: Dierauf L.A., Gulland F.M.D. (editors). CRC Handbook of Marine
Mammal Medicine: Health, Disease, and Rehabilitation. Second edition, CRC Press LLC, UK, 370-371.

Dennison S., Saviano P. (2001). Diagnostic imaging. In: Dierauf L.A., Gulland F.M.D. (editors). CRC Handbook of Marine Mammal Medicine: Health, Disease, and Rehabilitation. Second edition, CRC Press LLC, UK.

Elson-Riggins J.G., Al-Banna L., Platzer E.G., Kaloshian I. (2001). Characterization of Otostrongylus circumlitus from pacific harbor and northern elephant seals. Journal of Parasitology 87(1), 73-78.

Elson-Riggins J.G., Gibbons L.M., Van Liere D.W., Zinkstok E.W., Blake D.P., Alegre F., Spittle H., Brakefield P.M., Udo de Haes H.A., Osinga N. (2020). Surprisingly long body length of the lungworm Parafilaroides gymmurus from common seals of the Dutch North Sea. Parasitology Research 119, 1803-1817.

Gosselin J.F., Measures L.N., Huot J. (1998). Lungworm (Nematoda: Metastrongyloidea) infection in Canadian phocids. Canadian Journal of Fish and Aquatic Science 55, 825-834.

Gulland F.M.D., Beckmen K., Burek K. (1997). Nematode (Otostrongylus circumlitus) infestation of northern elephant seals (Mirounga angustirostris) stranded along the central California coast. Marine Mammal Science 13(3), 446-459

Lehnert K., Raga J.A., Siebert U. (2007). Parasites in harbour seals (Phoca vitulina) from the German Wadden Sea between two Phocine Distemper Virus epidemics Helgoland Marine Research 61, 239-245.

Lehnert K., von Samson-Himmelstjerna G., Schaudien D., Bleidorn C., Wohlsein P., Siebert U. (2010). Transmission of lungworms of harbour porpoises and harbour seals: Molecular tools determine potential vertebrate intermediate hosts. International Journal for Parasitology 40, 845-853.

Leidenberger S., Boström S. (2009). Description of the lungworm Otostrongylus circumlitus (Railliet, 1899) de Bruyn, 1933 (Metastrongyloidea: Crenosomatidae) found in the heart of harbor seals from Sweden. Journal of Nematode Morphology and Systematics 12(2), 169175 .

Measures L.N. (2001). Lungworms in marine mammals. In: Samuel W.M., Pybus M.J., Kocan A.A. (editors). Parasitic Diseases of Wild Mammals. Second edition, Iowa State University Press, USA, 279-283.

Moesker A. (1987). Treatment of infectious diseases in stranded harbor seals. Aquatic Mammals 13(2), 57-60.

Munro R., Ross H., Cornwell C., Gilour J. (1992). Disease conditions affecting commons seals (Phoca vitulina) around the Scottish mainland, September-November 1988. Science of the Total Environment 115, 67-82.

Onderka D.K. (1989). Prevalence and pathology of nematode infections in the lungs of ringed seals (Phoca hispida) of the Western Arctic of Canada. Journal of Wildlife Diseases 25(2), 218-244.

Siebert U., Wohlsein P., Lehnert K., Baumgärtner W. (2007). Pathological findings in harbour seals (Phoca vitulina): 1996-2005. Journal of Comparative Pathology $137,47-58$.

Stoskopf M.K. (2015). Parasitic diseases of marine mammals. MSD Veterinary Manual.

Ulrich S.A., Lehnert K., Rubio-Garcia A., Sanchez-Contreras G.J., Strube C., Siebert U. (2016). Lungworm seroprevalence in free-ranging harbour seals and molecular characterisation of marine mammal MSP. International 
Journal for Parasitology: Parasites and Wildlife 5, 4855.

Van Wijngaarden M.F.A., Geut M.I.M., Vernooij J.C.M., Ijsseldijk L.L., Tobias T.J. (2021). Determinants of mortality of juvenile harbor seals (Phoca vitulina) infected with lungworm submitted to a Dutch seal rehabilitation center. International Journal for Parasitology: Parasites and Wildlife 14, 1-6.

Vercruysse J., Salomez A., Ulloa A., Alvinerie M., Osterhaus A., Kuiken T. (2003). Efficacy of ivermectin and moxidectin against Otostrongylus circumlitus and Parafilaroides gymnurus in harbour seals (Phoca vitulina). Veterinary Record 152(5), 130-134.

\section{@creative}

(C) 2021 by the authors. Licensee Vlaams Diergeneeskundig Tijdschrift, Ghent University,

Belgium. This article is an open access article distributed under the terms and conditions of the Creative Commons Attribution (CC BY) license (http://creativecommons.org/licenses/by/4.0/).

\section{Grafstenen voor paarden in het Arley Arboretum (Severn vallei, Worcestershire, foto's 2018)}
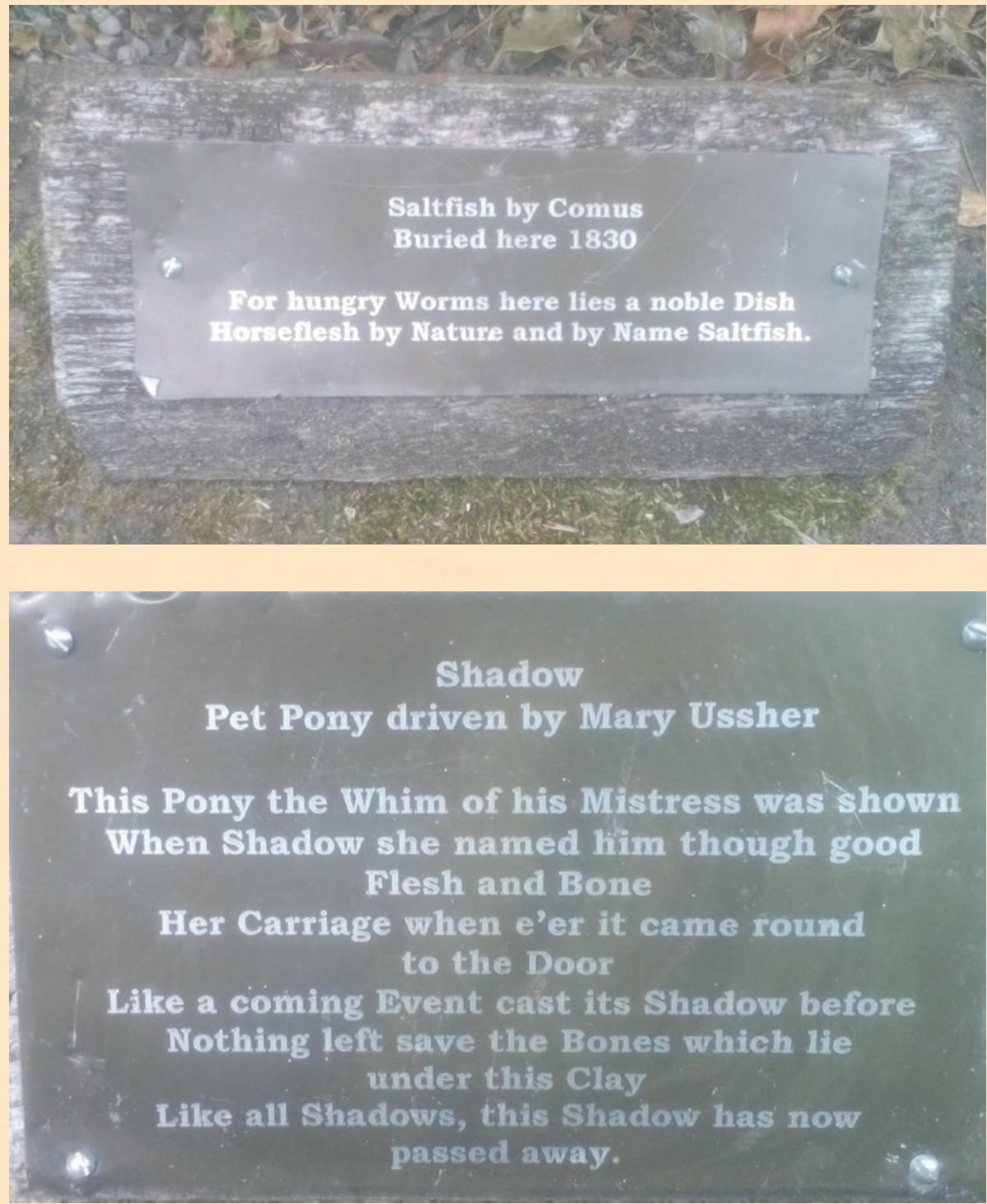